\title{
MOTIVATION OF THE ELDERLY AND ELDERLY VISITS TO THE ELDERLY INTEGRATED SERVICE POST (POSYANDU LANSIA) IN KLAMPISAN HAMLET, KEDUNGGEDE VILLAGE, DLANGGU SUB-DISTRICT, MOJOKERTO DISTRICT
}

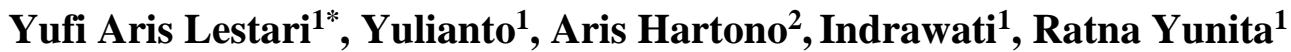 \\ ${ }^{1}$ STIKES Dian Husada Mojokerto \\ ${ }^{2}$ STIKES Bhakti Husada Mulia Madiun \\ *Correspondence: \\ Yufi Aris Lestari \\ Email: yufiarislestari@gmail.com
}

\begin{abstract}
Background: Having a healthy and prosperous life in old age is the hope of every elderly person. In achieving a healthy and prosperous old age, various efforts have been made by the government, one of which is an Elderly Integrated Service Post (Posyandu Lansia) program. Objectives: This study aimed to analyze the relationship of motivation of the elderly and elderly visits to the Elderly Integrated Service Post (Posyandu Lansia) in Klampisan Hamlet, Kedunggede Village, Dlanggu Sub-District, Mojokerto District.

Method: The research design used is analytic cross sectional. The population in this study were all elderly residents of Klampisan Hamlet, Kedunggede Village, Dlanggu Subdistrict, Mojokerto District who had attended the Elderly Integrated Service Post (Posyandu Lansia) as many as 52 people. The sampling technique in the study was simple random sampling. The sample size in this study was 46 people. The measuring instrument used was a questionnaire for motivational variables, and a visit book for elderly visiting to the Elderly Integrated Service Post (Posyandu Lansia) variables.

Results: The results showed that the average value of motivation was 68.5870, indicating strong motivation. The average visit value is 1.9348 , indicating that the visit is not active. Based on the results of the analysis using the Spearman Rho correlation test obtained $\rho=$ $0.00<\alpha=0.05$, so that it can be interpreted that there is a relationship between the motivation of the elderly and elderly visits to the Elderly Integrated Service Post (Posyandu Lansia) in Klampisan Hamlet, Kedunggede Village, Dlanggu Sub-District, Mojokerto District. Conclusion: Based on the results of the study showed that there was a relationship between the motivation of the elderly and elderly visits to the Elderly Integrated Service Post in Klampisan Hamlet, Kedunggede Village, Dlanggu Sub-District, Mojokerto District, which could mean that the elderly had strong motivation, then the visit to the Elderly Integrated Service Post would be active. On the contrary, the elderly whose motivation is weak then visit the Elderly Integrated Service Post (Posyandu Lansia) is not active.
\end{abstract}

Key words: Motivation of the elderly, elderly visits, the elderly integrated service post, posyandu lansia.

\section{INTRODUCTION}

One form of full active participation by the community is an integrated service post (Posyandu). The Elderly Integrated Service Post (Posyandu Lansia) is a manifestation of the implementation of government policy development programs in health services for the elderly. In addition, the Elderly Integrated Service Post (Posyandu Lansia) as a communications forum in the form of participation of elderly people, families, community and social organizations in its implementation so as to achieve optimal health improvement efforts (Sulistyorini, 2010). In fact, many elderly people do not come during the Elderly Integrated Service Post (Posyandu Lansia). This can cause their condition not to be monitored properly, so that if they experience a risk of illness due to a worsening of the body's condition, they can be fatal and threaten their 
lives. Reducing health access can be due to a decrease in promotive and preventive efforts through the activities of the elderly group. Reduced ability of the elderly to maintain healthy conditions independently and a decrease in the degree of health in the elderly will result in a decrease in the life expectancy of the elderly.

The number of elderly continues to increase and according to $\mathrm{WHO}$ projections in 1995 where, in 2050 compared to 1990 that the growth of the elderly population in Indonesia experienced the largest growth in Asia, which amounted to $41.4 \%$, Thailand $33.7 \%$, India 24.2 $\%$, and China $22.0 \%$. The number of elderly Indonesians themselves, according to BPS sources that in 2004 amounted to $16,522,311$, in 2006 amounted to $17,478,282$, and in 2008 amounted to $19,502,355$ ( $8.55 \%$ of the total population of $228,018,900$ ), while in the year 2020 is estimated to be around 28 million elderly. Currently, the data entered in the new Ministry of Health is 437 Elderly Health Centers, while in fact there are approximately 69,500 the Elderly Integrated Service Post (Posyandu Lansia) spread in several districts/ cities in Indonesia. Based on the data obtained from the Semarang District Health Office, it states that there are as many as 759 the Elderly Integrated Service Post (Posyandu Lansia) in Semarang District, However, there are as many as 735 the Elderly Intregated Service Post (Posyandu Lansia). Based on data obtained from the posyandu for the elderly in Candi village in November 2012, the attendance data for the last 3 months in August 24.1\%, September $30.1 \%$, October $26.5 \%$, showed that the presence of the elderly visit to the Elderly Integrated Service Post (Posyandu Lansia) was still lacking than expected. The target of the Elderly Integrated Service Post (Posyandu Lansia) program is at least $70 \%$ of the total number of the Elderly Integrated Service Post (Posyandu Lansia) targets (Indonesian Ministry of Health, 2010). Based on data obtained from the Solok City Health Office, the total population in Solok City is 36,737 people with the number of elderly 2,401 elderly, where the number of elderly people who come to the Elderly Integrated Service Post at 4 Public Health Centers (Tanjung Paku, Tanah Garam, Nan Balimo, KTK) from July Until September 2012, the Tanah Garam's Public Health Center had the smallest number of elderly visits among the three other public health centers. The Tanah Garam's Public Health Center has the highest number of elderly people, namely 795 elderly people, while the smallest number of elderly visits is July $40.7 \%$, August $38.9 \%$ and September 39.1\% (Dinkes Kota Solok, 2012). From the data obtained at the research site in Klampisan Hamlet, data was obtained in August 7\%, September 9\%, October 6\%.

Motivation is the relationship between needs, encouragement, and goals. Needs will arise because of something lacking that is felt by someone, both physiological and psychological. Encouragement is a direction to meet needs, while goals are the end of a motivation cycle. For example, the desire to live a healthy and productive life, so that individuals will maintain their health and check their health status regularly. The emergence of various health problems experienced by the elderly today, starting with the individual himself who is reluctant to regularly visit the Elderly Integrated Service Post (Posyandu Lansia) every month. So that their health status can not be monitored well.

The Elderly Integrated Service Post (Posyandu Lansia) is a manifestation of the implementation of government policy development programs in health services for the elderly. In addition, the Elderly Integrated Service Post (Posyandu Lansia) as a communications forum in the form of participation of elderly people, families, community and social organizations in its implementation so as to achieve optimal health improvement efforts (Sulistyorini, 2010). To achieve these goals and addressing the various phenomena that occur on the practitioners involved in the Integrated Services Posts (Posyandu) should provide an understanding of the elderly as well as improve the system of services that exist therein, among others, by improving existing facilities and infrastructure, increasing family support for the elderly, choosing locations that are easily accessible to the elderly, and as much as possible the Integrated Service Post cadres provide information before the implementation of the Elderly Integrated Service Post is carried out. By doing such activities, it is expected that there will be an increase in the motivation of the elderly to visit the Elderly Integrated Service Post, so that the elderly is able to obtain optimal health. 


\section{METHODS}

Study Design

The research design used was cross sectional

\section{Setting}

This research was conducted in Elderly Integrated Service Post (Posyandu Lansia) in Klampisan Hamlet, Kedunggede Village, Dlanggu Sub-District, Mojokerto District.

\section{Research Subject}

The population in this study were all elderly residents of Klampisan Hamlet, Kedunggede Village, Dlanggu Subdistrict, Mojokerto District who had attended the Elderly Integrated Service Post (Posyandu Lansia) as many as 52 people. The sampling technique in the study was simple random sampling. The sample size in this study was 46 people. Sample criteria in this study, among others:

a. Elderly who is willing to be a respondent.

b. Elderly who are in place at the time of the study.

c. Elderly who had attended an Elderly Integrated Service Post in Klampisan Hamlet, Kedunggede Village.

\section{Instrument}

This research was conducted by questionnaires.

\section{Data Analysis}

The results of this study were analyzed using the Spearmen Rho test with value of $\alpha=0.05$.

\section{RESULTS}

Characteristics of Respondents by Age of Parents

Age is one of the factors that influence a person's behavior. Age in this study varies from the age of 45 years to 80 years. The following is a table of the average distribution of respondents based on age.
Table 1. Distribution of respondents by age in the Elderly Integrated Service Post (Posyandu Lansia) in Klampisan Hamlet, Kedungdede Village, Dlanggu Sub-District, Mojokerto District $(n=46)$.

\begin{tabular}{cr}
\hline Age of Respondents & \\
\hline Mean & 57.4565 \\
Std. Deviation & 10.2387 \\
Minimum & 45.0000 \\
Maximum & 80.0000 \\
N & 46 \\
\hline Sources: Primary Data of Questionnaire
\end{tabular}

Based on Table 1 shows that the average respondent is 57.46 years old. Minimum age of 45 years and a maximum of 80 years.

\section{Characteristics of Respondents by Gender}

Based on Table 2 shows that most of the female were 31 respondents (67.4\%) and male were 15 respondents $(32.6 \%)$. Based on these data, there is a significant difference in proportion between elderly female and male to visit the Elderly Integrated Service Post (Posyandu Lansia). So, this study illustrates more interest of female visitors than male.

Table 2. Distribution of respondents by gender in the Elderly Integrated Service Post (Posyandu Lansia) in Klampisan Hamlet, Kedungdede Village, Dlanggu Sub-District, Mojokerto District $(n=46)$.

\begin{tabular}{ccc}
\hline Gender & Frequency & Percentage (\%) \\
\hline Male & 15 & 32.6 \\
Female & 31 & 67.4 \\
\hline Total & 46 & 100 \\
\hline Sources: Primary Data of Questionnaire
\end{tabular}

Characteristics of Respondents by Level of Education

The level of education influences awareness about the importance of health both in themselves and the environment, so as to encourage the need for health services, including the Elderly Integrated Service Post (Posyandu Lansia).

The level of education of respondent in this study varied from no school until 
university. The following is the distribution of respondents based on the level of education.

Table 3. Distribution of respondents by the level of education in the Elderly Integrated Service Post (Posyandu Lansia) in Klampisan Hamlet, Kedungdede Village, Dlanggu SubDistrict, Mojokerto District $(\mathrm{n}=46)$.

\begin{tabular}{lcc}
\hline \multicolumn{1}{c}{ The Level of Education } & Frequency & Percentage $(\boldsymbol{\%})$ \\
\hline No School & 9 & 19.6 \\
Elementary School & 25 & 54.3 \\
Junior High School & 9 & 19.6 \\
Senior High School & 2 & 4.3 \\
University & 1 & 2.2 \\
\hline \multicolumn{1}{c}{ Total } & 46 & 100 \\
\hline
\end{tabular}

Sources: Primary Data of Questionnaire

Based on Table 3 shows that more than half of elderly (54.3\%) completed Elementary School. Based on Table 3 shows that there is a difference in the proportion of elderly related educational backgrounds who visit the Elderly Integrated Service Post. From the data obtained, elderly who have elementary education dominated in this study.

Therefore, properly cadres and health workers provide information or counseling about the Elderly Integrated Service Post (Posyandu Lansia), so as to increase the motivation of the elderly to visit.

\section{Characteristics of Respondents by Marital Status}

Marital status of respondents in this study consisted of married and widow/ widower. The following is the distribution of respondents based on marital status.

Table 4. Distribution of respondents by the level of education in the Elderly Integrated Service Post (Posyandu Lansia) in Klampisan Hamlet, Kedungdede Village, Dlanggu SubDistrict, Mojokerto District $(\mathrm{n}=46)$.

\begin{tabular}{lcc}
\hline \multicolumn{1}{c}{ Marital Status } & Frequency & Percentage (\%) \\
\hline Married & 32 & 69.6 \\
Widow & 12 & 26.1 \\
Widower & 2 & 4.3 \\
\hline Total & 46 & 100 \\
\hline Sources: Primary Data of Questionnaire
\end{tabular}

Sources: Primary Data of Questionnaire
Based on Table 4 shows that most of the married were 32 respondents $(69.6 \%)$.

\section{Characteristics of Respondents by Occupational}

The occupational of respondents in this study consisted of farmers, housewives, retirees and entrepreneurs. The following is the distribution of respondents based on occupational.

Table 5. Distribution of respondents by occupational in the Elderly Integrated Service Post (Posyandu Lansia) in Klampisan Hamlet, Kedungdede Village, Dlanggu Sub-District, Mojokerto District $(n=46)$.

\begin{tabular}{ccc}
\hline Occupational & Frequency & Percentage (\%) \\
\hline Farmer & 40 & $87.0 \%$ \\
Housewives & 1 & $2.2 \%$ \\
Retirees & 1 & $2.2 \%$ \\
Entrepreneurs & 4 & $8.7 \%$ \\
\hline Total & 46 & $100 \%$ \\
\hline
\end{tabular}

Sources: Primary Data of Questionnaire

Based on Table 5 shows that as many as 40 respondents $(87 \%)$ worked as farmers.

\section{Motivation of Elderly}

From the results of the measurement of elderly motivation, it was found that respondents who had enough motivation were 27 people, which can be seen from the score range 62.50 - 66.25. Then, there were 19 respondents who had strong motivation which can be seen from the range of $67.50-81.25$. From the results of the measurement of motivation from 46 elderly, it shows that the average value of 68.59 shows strong motivation. The standard deviation value of the results of the study is 4.66 with the lowest value of 62.50 and the highest value of 81.25 and the value that often appears is 66.25 .

To determine the type of test, the normality test for each variable is performed. Normality testing is an important requirement that must be met in the path analysis. If the data analyzed is normally distributed, then the Pearson correlation test is chosen. If it does not meet the data requirements, the distribution is not normal, it must be attempted to transform the data so that the distribution becomes 
normal. If after being transformed the data becomes normal then the Pearson correlation test is chosen, if the results are transformed the data is not normal, then an alternative test is selected for the Spearman Rho correlation test. The normality test is based on the Kolmogorov test, namely if the significance value $<0.05$ (95\% confidence level) distribution is not normal.

From the normality test for motivation variables obtained a significance value of 0,000 . Because the value of $p<0.05$ in the motivation variable, it can be concluded that the data is not normally distributed.

\section{Elderly Visits to the Elderly Integrated Service Post (Posyandu Lansia)}

From the measurement of elderly visits to the Elderly Integrated Service Post (Posyandu Lansia), it was found that respondents who visited once were 24 people, respondents who visited 2 times were 10 people, respondents who visited 3 times were 8 people, respondents who visited 4 times were 1 person, respondents who visited 5 times were 1 person, and respondents who visited 6 times were 2 people. From the results of observations of elderly visits to the Elderly Integrated Service Post (Posyandu Lansia) in the past 1 year obtained from 46 respondents showed an average visit value of 1.93 which showed that respondents had less active visits, then for the standard deviation of 1.93 with the lowest value of 1 , the value highest 6 , and values that often appear 1 .

To determine the type of test, the normality test for each variable is performed. From the results of the normality test for the visit variable, the significance value is 0,000 . Because the value of $p<0.05$ on the visit variable can be concluded that the data is not normally distributed.

The Relationship between Motivation of Elderly and Elderly Visits to the Elderly Integrated Service Post (Posyandu Lansia) in Klampisan Hamlet, Kedunggede Village, Dlanggu Sub-District, Mojokerto District

From the results of the normality test of the two variables, the results are obtained that the data is not normally distributed. Then the original one will use the Pearson correlation test. Because the distribution data is not normal, the data does not meet the requirements to do Pearson correlation test, then the alternative test is chosen, namely the Spearman Rho correlation test.

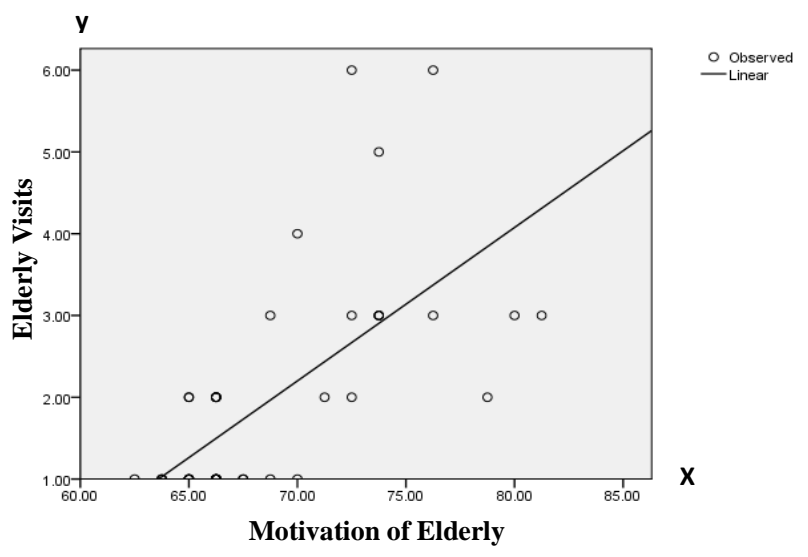

Figure 1. Linear Outline of the Relationship between Motivation of Elderly and Elderly Visits to the Elderly Integrated Service Post (Posyandu Lansia) in Klampisan Hamlet, Kedunggede Village, Dlanggu Sub-District, Mojokerto District

From the linear image above, it can be seen that $\mathrm{Y}$ tends to enlarge when $\mathrm{X}$ enlarges, so the correlation is called a positive correlation between motivation and visit (Murray, 2004). The results of the correlation test about the relationship between motivation of elderly and elderly visits to the Elderly Integrated Service Post (Posyandu Lansia) in Klampisan Hamlet, Kedunggede Village, Dlanggu Sub-District, Mojokerto District showed that a significance value of 0,000 indicates that the correlation between motivation of elderly and Elderly Visits to the Elderly Integrated Service Post (Posyandu Lansia) is meaningful. Spearman Rho correlation value of 0.712 indicates that the direction of positive correlation with strong strength.

\section{DISCUSSION}

\section{Motivation of Elderly}

From the results of the study, it was found that the motivation of the elderly to visits the Elderly Integrated Service Post (Posyandu Lansia), which was obtained from 46 respondents, showed a strong motivation average. The average elderly in Klampisan Hamlet, Kedunggede Village, Dlanggu SubDistrict, Mojokerto District only visits when they are sick. 
Swansburg (2001) defining motivation as a concept used for extrinsic conditions that stimulate the emergence of certain behaviors and intrinsic responses that show the behavior of a human being.

From the theory statement above it can be interpreted that motivation is a fundamental thing that makes someone take action. Motivation is the most important thing that makes people take action, so strong motivation influences the behavior of an elderly person to visits the Elderly Integrated Service Post (Posyandu Lansia).

The Elderly Integrated Service Post (Posyandu Lansia) in Klampisan Hamlet, cadres have tried to motivate the elderly by announcing the implementation of the Elderly Integrated Service Post (Posyandu Lansia) before the open day of the Elderly Integrated Service Post (Posyandu Lansia). However, even so, the elderly are still reluctant to visits the Elderly Integrated Service Post (Posyandu Lansia).

Abraham Maslow (1943) on Uno (2011) argued that basically all humans have basic needs. He shows it in 5 pyramid-shaped levels, people start encouraging from the lowest level.

From the results of the measurement of motivation obtained from the questionnaire distributed to respondents shows that the most influential motivation for the elderly to visit is hope. From the item question that was proposed, the elderly were motivated to visit because they wanted their health monitored. This is in line with the theory expressed by Maslow, because being healthy is a physical need, so every elderly person is motivated because his hope is to be healthy to meet his physical needs. Because basically motivation is a form of hierarchy, if the most basic needs, then someone will meet other needs. However, the results of the questionnaires distributed showed that the elderly were reluctant to visit the posyandu if they were not sick. This is inversely proportional to item number 1 if the elderly want their health monitored, but the elderly are reluctant to visit the Elderly Integrated Service Post (Posyandu Lansia) if they are not sick.

Elderly people tend to have a higher desire to visit the Elderly Integrated Service Post (Posyandu Lansia) if there is support from others. This shows that the support of others is very important to motivate the elderly to visit the Elderly Integrated Service Post (Posyandu Lansia). So, it is necessary to collaborate between families, cadres and health workers to provide support to the elderly to visit the Elderly Integrated Service Post (Posyandu Lansia).

A person's maturity also affects motivation, what is meant by maturity in this case is age. The age of a person influences motivation, on average the elderly age of the motivation begins to decrease, so there is a need for support from the family and the surrounding environment.

Motivation is not so influenced by information or the media, knowing or not does not affect the behavior of the elderly to visit the Elderly Integrated Service Post (Posyandu Lansia).

\section{Elderly Visits to the Elderly Integrated Service} Post (Posyandu Lansia)

The results of this study indicate that in general the elderly visits to the the Elderly Integrated Service Post (Posyandu Lansia) in Klampisan Hamlet, Kedunggede Village, Dlanggu Sub-District, Mojokerto District shows that the visit is not active.

The Elderly Integrated Service Post (Posyandu Lansia) is the implementation of the development program of government policy through health services for the elderly, as a communication forum in the form of participation of the elderly, families, leaders, communities and social organizations in its implementation, in an effort to increase optimal health levels (Ismawati, 2010). The Elderly Integrated Service Post (Posyandu Lansia) are integrated service posts for elderly people in certain areas that have been agreed upon, which are driven by the community where they can get health services.

From the above opinion, it can be interpreted that the Elderly Integrated Service Post (Posyandu Lansia) is an important activity that can improve the health and welfare of the elderly.

However, the elderly in Klampisan Hamlet rarely come voluntarily on the opening day of the Elderly Integrated Service Post (Posyandu Lansia). Elderly are reluctant to come when they are not sick, most of the elderly in Klampisan Hamlet think the Elderly Integrated Service Post (Posyandu Lansia) is a place for treatment, so if they are not sick, the 
elderly also does not need to join the Elderly Integrated Service Post (Posyandu Lansia).

The visit of the Elderly Integrated Service Post (Posyandu Lansia) is the arrival to visit the Elderly Integrated Service Post (Posyandu Lansia), with the aim of checking their health conditions (Novi, 2007).

Regular visit to the Elderly Integrated Service Post (Posyandu Lansia).

a. Regularity of visits to the Elderly Integrated Service Post (Posyandu Lansia) is to visit the Elderly Integrated Service Post (Posyandu Lansia) activities several times regularly at least 6 consecutive months (PPKM, 2000);

b. A visit to the Elderly Integrated Service Post (Posyandu Lansia) should ideally be carried out in at least one year at least 12 times.

But in reality no one in Klampisan Hamlet actively visited the Elderly Integrated Service Post (Posyandu Lansia). The average elderly only visits the Elderly Integrated Service Post (Posyandu Lansia) when they are sick. But if the elderly are healthy, the elderly are reluctant to come to the Elderly Integrated Service Post (Posyandu Lansia). So there needs to be socialization to arouse the desire of the elderly to visit, so that the goals of the Elderly Integrated Service Post (Posyandu Lansia) can be achieved.

The Relationship between Motivation of Elderly and Elderly Visits to the Elderly Integrated Service Post (Posyandu Lansia) in Klampisan Hamlet, Kedunggede Village, Dlanggu Sub-District, Mojokerto District

The results of the correlation of Spearman Rho on the motivation of Elderly variables and the variables of the elderly visit to the Elderly Integrated Service Post (Posyandu Lansia) indicate that there is a strong relationship between motivation and elderly visits to the Elderly Integrated Service Post (Posyandu Lansia) with a positive correlation direction. The correlation between motivation of Elderly and elderly visits to the Elderly Integrated Service Post (Posyandu Lansia) is meaningful.

Woodhworth in Sunaryo (2004) revealed that behavior occurs because of motivation or encouragement that directs individuals to act in accordance with the interests or goals to be achieved. Because without encouragement, there will be no force that directs the individual to a mechanism of behavior arising. Encouragement is activated by the need for need, in the sense that the need arouses encouragement, and this encouragement ultimately activates or raises the behavior mechanism.

Hull in Nursalam (2008) which asserts that a person's behavior is influenced by motivation or encouragement by the interests of fulfilling or satisfying the needs that exist in the individual. Further explained that behavior arises not solely because of encouragement that originates from individual needs, but also because of learning factors. This encouraging factor is conceived as a collection of energy that can activate behavior or as a motivational factor, where the emergence of behavior according to Hull is a function of three things, namely the strength of the drive that exists in the individual, the habits obtained from learning outcomes, and the interaction between the two.

Thus, it can be concluded that strong motivation can influence behavior so that an elderly visit to the Elderly Integrated Service Post (Posyandu Lansia) is realized. From the results of interviews with Kedunggede Village nurses who participated in managing the Elderly Integrated Service Post (Posyandu Lansia) in Klampisan Hamlet. It was found that most of the elderly who visited the Elderly Integrated Service Post (Posyandu Lansia) only if they were sick. Lack of active elderly in Klampisan Hamlet according to Kedunggede Village nurses may be due to the distance between Klampisan Hamlet and nearby Ponkesdes. So that the elderly prefer to come to Ponkesdes if they are sick because on average the elderly of Klampisan hamlet are reluctant to take the time to join the Elderly Integrated Service Post (Posyandu Lansia).

\section{CONCLUSION}

Based on the results of the study there are several things that can be concluded, among others:

1. The motivation of the elderly in Klampisan Hamlet, Kedunggede Village, Dlanggu Sub-District, Mojokerto District was categorized as strong motivation. This can be proven by the results of motivation 
measurements that get an average score that shows strong motivation.

2. From the results obtained regarding the Elderly visits to the Elderly Integrated Service Post (Posyandu Lansia), Klampisan Hamlet, Kedunggede Village, Dlanggu Sub-District, Mojokerto District showed that the visit was not active.

3. From the results of the study, it was found that there was a relationship between motivation and elderly visits to the Elderly Integrated Service Post (Posyandu Lansia) in Klampisan Hamlet, Kedunggede Village, Dlanggu Sub-District, Mojokerto District, meaning that the elderly who had strong motivation would be active too, and vice versa, the elderly who had weak motivations were also inactive, because motivation is a fundamental thing that stimulates the emergence of a behavior.

\section{SUGGESTION}

1. Need to carry out further research for researchers. This is because the research only revealed 1 aspect related to a visit to the Elderly Integrated Service Post (Posyandu Lansia). But actually, there are still many other aspects that have not been revealed in this study.

2. To be able to obtain empirical data and wider motivation about motivation and visits to the Elderly Integrated Service Post (Posyandu Lansia), further research is needed in order to generalize the results of the study to the wider target population.

\section{REFERENCES}

Ambarwati, Eny Retna. (2011). Asuhan Kebidanan Komunitas. Yogyakarta: Nuha Medika.

Dinkes Kota Solok. (2012). Profil Kesehatan Kota Solok. Dinas Kesehatan Kota Solok.

Dinkes Propinsi Jawa Timur. (2006). Buku Pegangan Kader Posyandu. Dinas Kesehatan Propinsi Jawa Timur.

Effendy, Nasrul. (1998). Dasar-dasar Keperawatan Kesehatan Masyarakat. Jakarta: EGC.
Ekasari, Ns. Mia Fatma. (2008). Keperawatan Komunitas "Upaya Memandirikan Masyarakat untuk Hidup Sehat". Jakarta: Trans Info Media.

Green, Laurence W. Health Program Planning an Educational and Ecological Approach. Marshall W. Kreuter. Rollins School of Public Health of Emory University.

Hamalik, Oemar. (2010). Pendidikan Guru Berdasarkan Pendekatan Kompetensi. Jakarta: PT. Bumi Aksara.

Herijulianti, dkk. (2001). Pendidikan kesehatan gigi. Jakarta: EGC.

Hidayat, R Dede. (2009). Ilmu Perilaku Pengantar Psikologi Untuk Tenaga Kesehatan. Jakarta: Trans Info Media.

Indonesian Ministry of Health. (2010). Panduan Tenaga Pelaksana Gizi Puskesmas dalam Pembinan Kader Posyandu. Kemenkes RI: Jakarta.

Komnas Lansia. (2010). Pedoman Pelaksanaan Posyandu Lanjut Usia. Jakarta: Komnas Lansia.

Makmun, H.A. Syamsuddin. (2005). Psikologi Kependidikan. Bandung: Remaja Rosdakarya.

Meilani, Niken, dkk. (2009). Kebidanan Komunitas. Yogyakarta: Fitramaya.

Notoatmodjo, S. (2003). Promosi Kesehatan dan Ilmu Perilaku. Jakarta: Rineka Cipta.

Notoatmojo, Soekidjo. (2007). Kesehatan masyarakat ilmu dan seni. Jakarta: Rineka cipta.

Nursalam. (2007). Manajemen keperawatan aplikasi dalam praktik keperawatan provesional edisi 2. Jakarta: salemba medika.

Nursalam, dkk. (2008). Pendidikan Dalam Keperawatan. Jakarta: Salemba Medika.

Purwanto, Heri. (1998). Pengantar Perilaku Manusia. Jakarta: EGC.

Purwanto, Ngalim. (2004). Psikologi Pendidikan. Bandung: Remaja Rosdakarya.

Pusat Bahasa Departemen Pendidikan Nasional. (2008). Kamus Besar Bahasa Indonesia. Jakarta: Balai Pustaka.

Robbins, Stephen P dan Judge, Timothy A. (2008). Perilaku Organisasi Buku 1, Jakarta: Salemba Empat.

Rusmi. (2008). Teori Movasi. Jakarta: Bintang Pustaka. 
Sardiman, A.M. (2006). Interaksi dan Motivasi Belajar Mengajar. Jakarta: Raja Grafindo Persada.

Sulistyorini, cahyo ismawati, dkk. (2010). Posyandu dan desa siaga panduan untuk bidan dan kader. Yogyakarta: Nuha medika.

Sunaryo. (2006). Psikologi untuk Kesehatan. Jakarta: EGC.

Sutikno, Raja Bambang. (2007). The Power of Empathy in Leadeship. Jakarta: Gramedia Pustaka Utama.

Swansburg, Russell C. (2001). Pengembangan staf keperawatan suatu komponen pengembangan SDM. Jakarta: EGC.

Uno, Amzah. (2008). Teori Motivasi dan Pengukurannya: Analisis Di bidang Pendidikan. Bumi Aksara.

Widayatun, Tri Rusmi. (2010). Ilmu Perilaku. Jakarta: Sagung Seto.

Yulianto, Y. (2018). Perilaku Kesehatan (1st ed.). Mojokerto: YAAM.

Yulifah R., Yuswanto. (2009). Asuhan Kebidanan Komunitas. Jakarta: Salemba Medika.

Zaidin, Ali. (2004). Teori Motivasi. Bandung: Pustaka Setia.

Cite This Article As: Lestari, Y. A., Yulianto, Hartono, A., Indrawati, Yunita, R. Motivation of The Elderly and Elderly Visits to The Elderly Integrated Service Post (Posyandu Lansia) in Klampisan Hamlet, Kedunggede Village, Dlanggu Sub-District, Mojokerto District. Nurse and Health: Jurnal Keperawatan 2018; 7(2): 124-132. 